\section{PRIZES PROPOSED BY THE PARIS ACADEMY OF SCIENCES FOR 1909.}

$G E O M E T R Y .-$ The Francœur prize, 1000 francs, is awarded annually for discoveries or work useful to the progress of pure and applied mathematics. For the Bordin prize, 3000 francs, the question proposed is as follows:-The absolute invariant which represents the number of distinct double integrals of the second species of an algebraic surface depends on a relative invariant $\rho$, which plays an important part in the theory of the integrals of total differentials of the third species and in that of algebraic curves traced on the surface. It is proposed to make a profound study of this invariant, and especially to find out how to determine its exact value, at least, for numerous kinds of surfaces.

Mechanics.-A Montyon prize, 700 francs, for inventing or improving instruments useful to the progress of agriculture, the mechanical arts, or sciences. The Poncelet prize will be awarded for a work on applied mathematics. The question for the Vaillant prize, 4000 francs, is to improve in an important point the application of the principles of the dynamics of fluids to the theory of the screw. The Boileau prize, 1300 francs, is for researches on the motion of fluids, sufficient to contribute to the progress of hydraulics.

Navigation.-The Plumey prize is for improvement of steam engines or any other invention which has most contributed to the progress of steam navigation.

Astronomy. - The Lalande prize, 540 francs, is for the most interesting observation, memoir, or work useful to the progress of astronomy, and the Valz prize, 460 francs, is awarded on similar terms. The G. de Pontécoulant prize, 700 francs, is for the encouragement of researches in celestial mechanics.

Geography.-The Tchihatchef prize, 3000 francs, for the recompense or encouragement of young naturalists distinguished in the exploration of the lesser known parts of Asia.

The Gay prize, 1500 francs, for the study of the geographical distribution of one class of cryptogams.

Physics.-The Hébert prize for the author of a treatise or discovery for the application or practical employment of electricity; the Hughes prize, 2500 francs, for a discovery or work contributing to the progress of physics; the Gaston Planté prize, 3000 francs, for the discovery of an invention or important work in the field of electricity; the L. La Caze prize, Io,ooo francs, which cannot be divided, for works or memoirs contributing to the progress of physics.

Chemistry.-The Jecker prize, 10,000 francs, for works contributing to the progress of organic chemistry; the Cahours prize, 3000 francs, for the encouragement of young chemists; the Montyon prize (unhealthy trades), a prize of 2500 francs and a mention of 1500 francs, for the discovery of a means of rendering an art or trade less unhealthy; the L. La Caze prize, ro,00o francs, which may not be divided, for the best work in chemistry.

Mineralogy and Geology.-The grand prize of the physical sciences, 3000 francs. The question proposed for I 909 is the stages of evolution of the most ancient quadrupeds found in France. The Delesse prize, I 400 francs, for a work concerning geology, or, in default, mineralogy.

Botany.-The Desmazières prize, I600 francs, for a work on cryptogams; the Montagne prize, I500 francs, for important work bearing on the anatomy, physiology, development, or description of the lower cryptogams; the de Coincy prize, goo francs, for a work on phanerogams the Thore prize, 200 francs, for a memoir on the cellular cryptogams of Europe.

Anatomy and Zoology.-The Savigny prize, 1500 francs, for the assistance of young travelling zoologists, not receiving Government assistance, who occupy themselves more especially with the invertebrates of Egypt and Syria the Da Gama Machado prize, for the best memoir on the coloured parts of the tegumentary system of animals.

Medicine and Surgery. - The Montyon prize, a prize of 2500 francs, and mentions of 1500 francs, for works or discoveries useful in the art of healing; the Barbier prize, 2000 francs, for a discovery in surgical, medical, or pharmaceutical science, or in botany with relation to medicine; the Breant prize, I0o,00o francs. The capital sum will be awarded under the terms of the legacy to anyone discovering a radical cure for Asiatic cholera, either by a specific medicine or by discovering the causes and indicating an undoubted method of destroying these causes. In default of this, the annual interest will be awarded for a memoir demonstrating in a rigorous manner the presence of materials in the atmosphere playing a part in the production or propagation of epidemic diseases. The Godard prize, Iooo francs, for the best memoir on the anatomy, physiology, or pathology of the genitourinary organs; the Baron Larrey prize, 750 francs, for an army or navy doctor or surgeon for a work treating of military medicine, surgery, or hygiene; the Bellion prize, I400 francs, for work forwarding the progress of medicine; the Mège prize, interest on 10,000 francs.

Physiology.-The Montyon prize, $75^{\circ}$ francs, for work in experimental physiology; the Philipeaux prize, 900 francs, for similar work; the Lallemand prize, I80o francs, for researches on the nervous system. The question proposed for the Pourat prize, Iooo francs, for 1909, is the origin of the anti-ferments.

Statistics.-A Montyon prize, prize 1000 francs and a mention of 500 francs, for work having a bearing on French statistics.

History of Science.-The Binoux prize, 2000 francs, for works on the history of science.

General Prizes.-The Arago, Lavoisier, and Berthelot medals. The Gegner prize, 3800 francs, for researches in the positive sciences; the Lannelongue prize, 2000 francs, for the assistance of the relatives of scientific men; the Trémont prize, I 100 francs. The Wilde prize, one of 4000 francs and two of 2000 francs, for work in astronomy, physics, chemistry, mineralogy, or experimental mechanics the Longchamp prize, 4000 francs, for a work on the diseases of man, animals, and plants, from the special point of view of the introduction of excess of mineral substances as the cause of disease; the Saintour prize, 3000 francs; the Victor Raulin prize, 1500 francs, to facilitate the publication of works relating to geology and palæontology, mineralogy and petrography, meteorology and physics of the globe, the prize for 1909 being limited to mineralogy and petrography ; the prize founded by Mme. la Marquise de Laplace; the Félix Rivot prize, 2500 francs; the Jean Jacques Berger prize, 15,000 francs, for work concerning the City of Paris; the Petit d'Ormoy prize two prizes of ro,0oo francs, one for pure and applied mathematics, and the other for natural science; the Pierson-Perrin prize, 5000 francs, for a physical discovery; the Parkin prize, 3400 francs, for researches on the curative effects of carbon in cholera, different forms of fever, and other diseases, or on the effects of volcanic action on the production of epidemic diseases; the Cuvier prize, I500 francs, for a work on zoological palæontology, comparative anatomy, or zoology.

Of the above, the Lalande, Tchihatchef, La Caze, Delesse, Desmazières, and Wilde prizes, and the Lavoisier medal, are expressly offered without distinction of nationality; the Gaston-Planté, Montagne, and PiersonPerrin prizes are limited to persons of French nationality.

\section{RECENT WORK OF GEOLOGICAL SURVEYS.}

THE Geological Survey of Great Britain has issued its "Summary of Progress for 1906" (1907, price 1s.), from which it is clear that a large part of the work of the staff must always be devoted to the revision of geological details in areas already mapped. This is not work that can be carried out hurriedly, or in response to every change in popular geological opinion; but the real need for re-consideration in accordance with modern discovery is at once apparent from the results recorded on pp. 2 to 5 of the present summary. Geological surveys have an important educational duty in addition to their economic functions, and one can never predict where an accurate knowledge of the earth may not lead to the foundation of an industry, or where an industrial inquiry may not suddenly illumine our relation to this globe on which we have to spend our lives.

It is pleasant to observe (p. 6) that the Geological Survey of Great Britain has been in conference with the Agri- 
cultural Education Association " for the purpose of testing the relationship of the geological boundaries and the soils." On p. I IO the palæontologists report in favour of the view that the rugose corals were primarily hexamerous, a question still under discussion, as may be seen from a note in Nature, vol. lxxvi., p. I17. The original papers in the appendix, corresponding to the well-known Bulletins of the Geological Survey of the United States, include one by Dr. Flett on the scapolite-bearing rocks of Scotland, and a valuable summary by Mr. D. A. Macalister of the quantity of tin, copper, and other minerals produced in Cornwall.

The "solid" and "drift" maps, Nos. 230 and 247, are issued simultaneously with the memoirs describing them, under the care of Dr. Aubrey Strahan, and cover parts of the great South Wales coalfield (1907, memoirs, price $2 s$. $6 d$. each; maps, Is. $6 d$. each). The former memoir deals with the country round Ammanford, north of Swansea, where the Silurian strata, through the Ludlow Tilestones, pass up into the Red Marls that form the base of the Old Red Sandstone. The usual unconformity of the latter on a Caledonian land-surface is revealed, however, by the fact that it oversteps every member of the Silurian system (p. 53), until it rests directly on the Arenig rocks in the extreme north-west of the map. The details shown on these modern maps necessitate a good deal of freedom in the use of colours, and blues and greens and yellows are used for lithological divisions (which are, of course, supported by palæontology) in a way that would hardly commend itself to the soul of William Smith. Would not a variety of linings and stipplings in the same colour, which produce all the effect of separate tints, serve on such colour-printed maps for minor subdivisions of our British systems? The American and New Zealand surveys often provide us with examples.

We note (p. 37 of Memoir No. 230) that "Ordovician" now officially replaces the "Lower Silurian" of the older survey ; but is it wise to restrict "Silurian," in the face of almost all the geological world, to the former "Upper Silurian" alone? Prof. De Lapparent in 1893 at any rate showed us a clear way out of the difficulty.

Memoir No. 247 includes the busy town of Swansea, and the map brings us to the southern edge of the great coalfield. Mr. E. E. L. Dixon (pp. I I-20) furnishes an interesting account of the dolomitisation of the limestone soon after its deposition in the Carboniferous sea, and the plates and descriptions ought to be useful to workers in many other districts. The growing difficulty in drawing a line between the Lower and Upper Carboniferous series in Britain is well seen by the remarks on pp. 28-29. Mr. Tiddeman (p. I2I) has traced a pre-Glacial raised beach from Mumbles Head westward, the fauna of which shows that the whole Cainozoic Glacial epoch was an episode of our own times, if we take the mollusca as our guide. It is now urged (p. 127) that Rhinoceros, Elephas, Bos, and Cervus, founa in the Gower Caves, lived here before the arrival of the ice, since raised beach deposits admittedly appear in the cavern-floors. The subsidence that was shown at the Barry Docks in Cardiff to be later than Neolithic times has carried peat in the Swansea area (p. 145) to a level of 44 feet below high water.

The memoir on the geology of Islay has also appeared (1907, price 2s. 6d.). The author, Mr. S. B. Wilkinson, is referred to in other memoirs as Mr. B. S. N. Wilkinson, a point of which bibliographers should take notice. The maps here described were issued some years ago, and cover a little visited and very attractive district. The ordinary pedestrian in Jura and Islay will find much romantic ground, and may still travel by introduction from one farm to another, in the good old highland style. The present writer well remembers how he was waylaid by an old peasant woman early one morning on the Jura pathway, and forced to accept a parcel of oatcake, lest he should weary before reaching the ferry at the north end of the island.

Mr. Wilkinson enables us, in his first chapter, to realise the main features of Islay, and he rightly directs attention to the extreme brilliance of the colouring on sunlit davs along the coast. The rocks include much crushed and mylonitic Lewisian gneiss; sediments regarded as Torridonian; phyllites, limestones, and quartzites, corre- lated with the Central Highland series; and, resting on these with a slight unconformity (p. 44), a series in which dolomite is prevalent. A considerable thrust-plane separates the quartzite and conglomerate of this series in the north of the island from the rocks referred to the Torridonian. Drs. Teall and B. N. Peach have made important contributions to this memoir. It is illustrated by photographic plates of exceptional beauty. It was unnecessary, however, to supply Plate ii. in our copy in the condition of a " proof before letters."

In the Verhandlungen der k.k. geologischen Reichsanstalt for 1907 , Herr Vacek (p. 159) continues the controversy with Herr Heritsch on the basin of Graz, and we are led to understand that the junior author, whose youth is greatly insisted on, may now be carried off the field. $\mathrm{He}$ is sagely advised not to quote authorities, but to become one himself. Surely we have heard something of this kind in geological exhortations nearer home.

Herr Ampferer (p. 192), in his usual systematic style, gives a reading of the structure of the Rhätikon range on the Swiss and Austrian frontier, in which he shows that he is not fascinated by what Schardt has called "Ultranappismus." Ampferer goes so far as to suggest that certain foreign blocks amid Tithonian limestone, regarded by von Seidlitz as evidence of a "Fenster," and thus connected with overfolding, have been brought into their present position by ice which overrode the chain.

The Jahrbuch of the same institute for 1907 contains many descriptive papers, from von Troll's study of the Pontic fauna in the basin of Vienna (p. 33) to Schubert's work on the north Dalmatian coast (p. I). Dr. Schubert incidentally opposes the suggestion, made from a study of old maps, that extensive geographical changes have occurred in the Adriatic isles within historic times.

Dr. Hinterlechner (pp. I I5-374) contributes an important memoir on the sheet of the map round Deutschbrod (Némecký Brod, the German ford), in eastern Bohemia. A broad plateau of gneiss and granite here unites Bohemia and Moravia; the traveller may find it monotonous, but for the fantastic architecture of its towns. Dr. Hinterlechner shows what problems of metamorphism lie beneath its undulating fields and little woods. He urges (p. 332) that the great mass of the cordierite and biotite gneisses result from the contact-alteration of a sedimentary series, which has been left intact in one particular zone. Rocks once regarded as Archæan are shown to be intrusive in this sedimentary envelope (p. 35r), the age of which remains uncertain. Here again we note the striking change of opinion forced on observers in many lands when careful field-investigation comes to be carried on. Almost all our recent researches lead us farther away from the supposed Archæan crust of purely igneous origin.

Walery Ritter von Loziński describes in the same journal (p. 375) the glacial deposits and löss of northern Galicia, and traces the ice-tongues of the epoch of maximum glaciation into the northern valleys of the central Carpathian range. He finds (p. 395) that the thin marginal ice of the great continental sheet moved to a considerable height up gentle slopes, but was unable to climb steeper hillsides. Unglaciated areas therefore appear, say 250 metres above the sea, side by side with others invaded by ice to a height of 300 metres.

Among palæontological papers may be cited a iong memoir by Dr. A. Till on the jaws of fossil cephalopods (ibid., pp. 535-682), an outcome of his previous studies on the examples found in the Neocomian (ibid., 1906, p. 89). Four new genera are proposed, and the jaws belonging to Nautilus are marked off clearly from all others (p. 658). The latter types diminish rapidly at the close of Lower Cretaceous time, and the author (p. 680), in consequence, suggests that they were connected with the Belemnoidea. Throughout both the memoirs referred to, Dr. Till writes "Rhynchotheutis" and "Palæotheutis" consistently; but surely this is a curious error in one who is so much a specialist.

The Bulletins de la Commission géologique de Finlande are always of interest. In No. 23 (June, I907) Mr. Sederholm writes, with an English summary, on "granite and gneiss, their origin, relations, and occurrence in the pre-Cambrian complex of Fenno-Scandia." The subject is one in which the author has already made a reputation. Like HinterNO. I991, VOL. 777 
lechner, quoted above, and many others, he has been forced here to oppose the notion of a primitive crystalline crust, revealed to us in a region of Archæan rocks, and urges that the oldest rocks in this district are of sedimentary origin, penetrated by younger granites. "The strongly contorted structure " (p. 99) " characteristic of most Finnish gneisses . . . is not a secondary phenomenon in truest sense, but originated when the rock was in a

In the "Administration Reports of Ceylon for I906 (Mineralogical Survey)," Dr. Coomaraswámy records the discovery of thorianite in situ by $\mathrm{Mr}$. Parsons in a vein of pegmatite, to which the mineral was traced by following up the alluvial deposits in the bed of a seasonal stream. About $6 \mathrm{lb}$. of thorianite occur in a ton of the wet decomposed pegmatite. A geological map of part of the Kandy district is added to the report.

Vol. vi. of the "Records of the Mysore Geological Department " contains several coloured maps. It is suggested that the manganiferous laterite in the Shimoga district, now being mined, may represent an old lake-deposit. The work done by the survey is of a wide character; but may we suggest that such terms as "geology student" and "topo sheets " do not fairly represent the Engtish language?

The "Geologists' Report of Progress for September, 1903, to January. 1907, for the Federated Malay States," by Mr. J. B. Scrivenor (Kuala Lumpur, 1907, price I dollar), is another interesting piece of evidence as to present geological activity. A distinct foundation is laid in this pamphlet for a conception of the structure of the south end of the Malay peninsula, but the dense vegetation is here, as in Borneo, a serious obstacle to the explorer. On p. I8 there is a remarkable reference to $\mathrm{Mr}$. H. N. Ridley's discovery of an alga instrumental in producing laterite. Of this we shall hope to hear much more;

Fig. x.-Miocene strata, near Rockville, west of Golden Bay, Nelson, New Zealand.

melting condition." This is supported by a series of photographs of rocks intimately penetrated by granite veinlets. The author "regards the foliation of the granites, where it is not of dynamo-metamorphic origin, as formed by the incomplete melting and re-crystallisation of schistose rocks. Also the spotting of granites, he ascribes, in most cases, to the existence of incompletely resorbed fragments of older rocks."

At the same time, he believes that the foliation of many Finnish granites was due to pressure after they had become solid (p. 1oo), and that in Finland " the basement complexes of the typical Archæan sedimentary formations are often preserved." But the base of the whole series in Fenno-Scandia has been melted up; mixed rocks, therefore, play a very important part in this area. Hutton's conception of the circulation of types of rock through denudation of the crystalline masses and their gradual renewal, appears to Sederholm to be fully justified (p. 102). The word " migniatite" is proposed for the rocks that have been called by others " composite gneiss."

In Bulletin No. 21 Mr. Tanner continues his studies on the glacial phenomena of Finmark, and urges that, allowing for temporary advances of the ice during a general epoch of recession, the glaciation may here be regarded as continuous, without an interglacial break.

Turning eastward, we find Dr.

W. F. Hume reporting on the geology of the eastern desert of Egypt (Ministry of Finance, Survey Department, Cairo, 1907). Gold-mining was carried on here in ancient days, and has recently been revived; the gold occurs in quartz-veins. The present account of the geology is merely preliminary, but includes the record (p. 29) of a new marine fauna in the Cretaceous sandstone.

No. I99I, vor. 77] possibly Mr. T. H. Holland, the originator of the organic view of laterisation, has already looked into the matter.

Bulletin No. 3 of the New Zealand Geological Survey contains Mr. J. M. Bell's report on the Parapara subdivision, Karamea, at the north-west corner of the South Island. It is well furnished with landscape illustrations, as is usual with these publications, and a series of beauti-

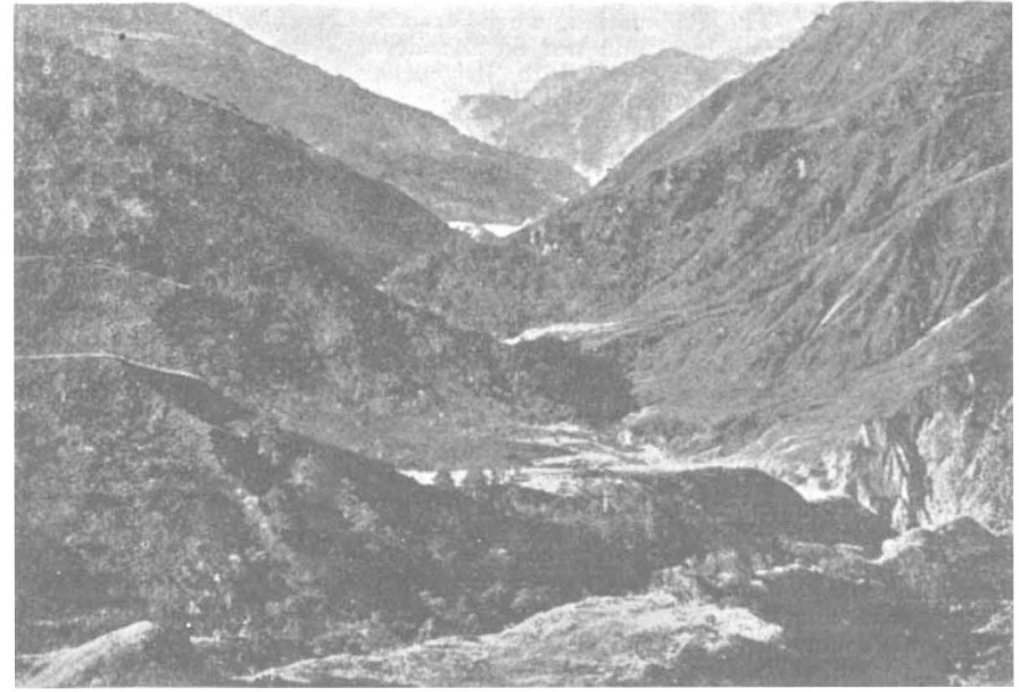

FIG 2.-Bued River Valley, northern Luzon, Philippine Islands.

fully executed maps is inserted in a pocket at the end. The geological history of the district in Cainozoic times emphasises our growing convictions as to the almost world-wide occurrence of the same physical phenomena in certain geological epochs. In this corner of New Zealand, as in central Europe and Armenia, for example, we have a Miocene depression, with a marine invasion (see Fig. I), occupying the valleys of the previous land, and then "a 
period of secular elevation, accompanied by faulting on an extensive scale. Gradual uprise of the land was continued practically into modern times." An epoch of extensive glaciation, with the formation of an ice-sheet in the basin of Boulder Lake, then opened in Pliocene or postPliocene times (p. 22). Especial attention is directed in this bulletin to the immense deposits of limonite iron-ore associated in the district with an ancient series of carbonate rocks. The ore is ascribed to the decay of iron pyrites, and to the reaction of the resulting ferrous sulphate on the carbonates. The ferrous carbonate has finally been altered to limonite, probably as a surface-phenomenon; but the resulting ores occur on a vast scale, highly encouraging for their future prospects (pp. 75-88).

The Bureau of Science of the Government of the Philippine Islands is responsible for the admirably produced Philippine Journal of Science, an example to our Government printers in India, or perhaps an example of the disparity of the funds officially devoted in the two countries to scientific publications. In vol. ii., No. 4 (Manila, August, 1907), Mr. A. J. Eveland describes the geology and geography of the Baguio mineral district. Here again, in the island of Luzon, we find an old crystalline basis, marine Eocene (?) and Miocene beds laid down upon it, and then an epoch of elevation and denudation. The Miocene limestone is cut through by the present Bued River valley, which reaches down to the basal diorite (Fig. 2). G. A. J. C.

\section{ARCHAOLOGY IN AMERICA.1}

THE first part of the second volume of the Transactions of the Universitv of Pennsylvania's Department of Archæology, Free Museum of Science and Art (it is a pity that this cumbrous title cannot be simplified), contains the usual instalment of articles on Cretan and Mexican archæology, with interesting contributions by $\mathrm{Mr}$. G. B. Gordon on the western Eskimo of Alaska and on an engraved bone from Ohio, the decoration of which is very Mexican in character. The author of the article on Mexican archæology, Miss Adela Breton, draws interesting analogies between the Mexican conventional representations of serpents and the dragons of Chino-Japanese art. There certainly seems to be some connection, however it may be explained. The explanation, when it arrives, will, however, be a genuine one, and not on the lines of the late Mr. Donnelly's "Atlantis," with its curious comparisons of Maya signs with "Egyptian hieroglyphics," most of which had no real existence. It is a pity that the investigation of possible connections between Mexican culture and those of the rest of the world has been so seriously discredited by the "Atlantis" idea. Miss Breton's description of the Xochicalco temple is interesting reading.

Mr. Gordon describes, among other "ploys" of the Eskimo, their elaborate cat's-cradle games. From a personal trial we cannot say that his recipes for their production are as clearly put as they might be. The photographs of these Eskimo which Mr. Gordon publishes show a Mongol rather than American type; plate v., 2, might, but for the eyes being rather too deeply set, be a Japanese.

The Cretan contribution is a good article on "The Decorative Art of Crete in the Bronze Age," by Miss Edith H. Hall, who worked at Gournià with Miss Boyd (Mrs. Hawes). As a succinct description of the most striking characteristics of the succeeding "Minoan" periods of Cretan artistic development it is very useful, and supplements Dr. Evans's "Essai de Classification" and Dr. Mackenzie's articles on pottery in the "Journal of Hellenic Studies" and the "Annals of the British School at Athens." In tone Miss Hall is perhaps just a trifle too dogmatic, and dismisses the opinions of others (e.g. Messrs. Hogarth and Welch once or twice) too summarily. On Egyptian matters, too, she is inclined to regard as certain what those who deal with Egyptian things at first-

1 University of Pennsylvania : Transactions of the Department of Archæ ology. Free Museum of Science and Art, vol. ii., nart i. Pp. 105; 29 plates. (Philadelphia: Published by the Department of Archæology, Igo6.) Price

NO. I99I, voL. 77] hand know to be thoroughly uncertain. The later system of Egyptian dates is adopted (p. 12) from Prof. Breasted's history with hardly a qualm, in spite of the fact that it is not yet accepted by Petrie, Maspero, von Bissing, or Budge (to give only the most prominent names). There are growing reasons in favour of it, true; but equally there are most serious considerations to be urged against it. To talk dogmatically of the VIth Dynasty as ending "in 2475 B.c." (the italics are mine), or the XIIth as dating "from 2000 to 1788 B.c.," is absurd, though Miss Hall is not responsible for the absurdity.

Also, Miss Hall makes the usual mistake of the Greek archæologist, a mistake which we had occasion to correct in the case of her colleague Mr. Seager last year, in persistently regarding all Egyptian representations of plants, flowers, and so forth, as stiff and conventional. They are not invariably so, as a study of plant designs on XVIIIth Dynasty pottery from Deir el-Bahari and elsewhere shows; it is these, and not the formal dadoes of papyrus plants in wall paintings, that we must compare with the plant designs of the Cretan artists. Miss Hall's Fig. 29 is quoted as a Cretan " adaptation of the lotus clumps of Egyptian art. Here the method of arranging the flowers," she says, " is the same as in Egyptian art, yet every trace of Egyptian stiffness is gone." I could quote several examples of Egyptian representations of flowers that are far less stiff and formal than this Cretan one. The designs of Figs. 35,48, and 49 could all be paralleled on Egyptian pottery.

Miss Hall's classificatory table of "Cretan Bronze Age Design" is very useful as a conspectus of the chief examples of the designs of the "Minoan" periods.

\section{H. R. Hall.}

\section{THE PELYCOSAURIAN REPTILES. ${ }^{1}$}

$A$ LMOST exactly thirty years ago the late Prof. Cope brought to the notice of the scientific world remains of certain remarkable carnivorous reptiles from the Permian strata of Texas, for which he proposed the group-name Pelycosauria. The group was regarded as a suborder of the Rhynchocephalia, and was provisionally taken to include the theriodont reptiles of South Africa. Among the more typical representatives of the pelycosaurs are Dimetrodon and Naosaurus, extraordinary reptiles in which the dorsal spines of the trunk vertebræ are so enormously elongated (sometimes with the addition of transverse projections) that they exceed in height the depth of the body below them. Restorations of both the skeleton and the external form have now rendered these creatures familiar even to the man in the street.

As to the systematic position of these reptiles and their kindred, considerable diversity of view has obtained. By many writers they are classed with the theriodont anomodonts, but this, according to modern ideas, is altogether unjustifiable, the structure of the temporal arches in the two groups being different. Dr. Case therefore reverts to the original view that pelycosaurs form a primitive section of the rhynchocephalians.

The group is of special interest as illustrating, perhaps better than any other, the rapid evolution from a generalised type to a complex organisation that may have been the potential cause of early extinction, the life of these reptiles being coterminous with the duration of the Permian epoch. Why these specialised structures were evolved within such a comparatively short time is a subject upon which we can only conjecture. Carnivorous in habit, and easily masters of their contemporaries, these reptiles, Mr. Case suggests, may have developed their spines from mere exuberance of growth from a utilitarian beginning, but that these structures eventually became useless cannot be doubted.

That pelycosaurs existed outside of North America is proved by the occurrence of Naosaurus in the Permian of Bohemia and of Stereorhachis in that of France, while certain reptiles from central Germany may also belong to the group. On the other hand, they are unknown in South

1 "Revision of the Pelycosauria of North America." By E. C. Case Puhlication No. 55. Pp. 176+35 plates. (Carnegie Institution, Washington,
D.C., 1907.) 